\title{
Ubuntu and the body: A perspective from theological anthropology as embodied sensing
}

\begin{tabular}{|c|c|}
\hline \multicolumn{2}{|c|}{$\begin{array}{l}\text { Author: } \\
\text { Jacob J.S. Meiring }{ }^{1}\end{array}$} \\
\hline $\begin{array}{l}\text { Affiliation: } \\
{ }^{1} \text { Department } \\
\text { and Christian } \\
\text { University of } \\
\text { South Africa }\end{array}$ & $\begin{array}{l}\text { ff Dogmatics } \\
\text { Ethics, } \\
\text { retoria, }\end{array}$ \\
\hline $\begin{array}{l}\text { Corresponden } \\
\text { Jacob Meiring }\end{array}$ & ce to: \\
\hline $\begin{array}{l}\text { Email: } \\
\text { jacob@bodytt }\end{array}$ & heology.co.za \\
\hline $\begin{array}{l}\text { Postal addres } \\
766 \text { Beyers Str } \\
0084 \text {, South A }\end{array}$ & $\begin{array}{l}\text { s: } \\
\text { reet, Rietfontein } \\
\text { frica }\end{array}$ \\
\hline $\begin{array}{l}\text { Dates: } \\
\text { Received: } 12 \\
\text { Accepted: } 10 \\
\text { Published: } 18\end{array}$ & $\begin{array}{l}\text { Ap. } 2015 \\
\text { Apr. } 2015 \\
\text { June } 2015\end{array}$ \\
\hline $\begin{array}{l}\text { How to cite th } \\
\text { Meiring, J.J.S., } \\
\text { 'Ubuntu and t } \\
\text { perspective fr } \\
\text { anthropology } \\
\text { sensing', Verb } \\
36(2), \text { Art. \#14 } \\
\text { http://dx.doi. } \\
\text { ve.v36i2.1423 }\end{array}$ & $\begin{array}{l}\text { is article: } \\
2015 \text {, } \\
\text { he body: A } \\
\text { om theological } \\
\text { as embodied } \\
\text { um et Ecclesia } \\
23,8 \text { pages. } \\
\text { org/10.4102/ }\end{array}$ \\
\hline $\begin{array}{l}\text { Note: } \\
\text { This article res } \\
\text { research done } \\
\text { thesis, 'Theolc } \\
\text { Exploring the } \\
\text { from a southe } \\
\text { perspective'. T } \\
\text { degree was av } \\
\text { the University } \\
\text { and the Vrije } \\
\text { Amsterdam, n } \\
\text { Prof. Dr J.C. M } \\
\text { Prof. Dr E.A.J.C } \\
\text { Borght as sup }\end{array}$ & $\begin{array}{l}\text { ulted from } \\
\text { for my PhD } \\
\text { gy in the flesh: } \\
\text { corporeal turn } \\
\text { rn African } \\
\text { his joint } \\
\text { varded by } \\
\text { of Pretoria } \\
\text { Jniversiteit, } \\
\text { vith } \\
\text { üller and } \\
\text { G. van der } \\
\text { ervisors. }\end{array}$ \\
\hline $\begin{array}{l}\text { Research Part } \\
\text { Ubuntu-Resea } \\
\text { the University }\end{array}$ & $\begin{array}{l}\text { icipant in the } \\
\text { of project of } \\
\text { oretoria. }\end{array}$ \\
\hline $\begin{array}{l}\text { Copyright: } \\
\text { (C) 2015. The A } \\
\text { Licensee: AOS } \\
\text { OpenJournals. } \\
\text { licensed unde } \\
\text { Commons Attr }\end{array}$ & $\begin{array}{l}\text { ISthors. } \\
\text { IS } \\
\text { This work is } \\
\text { r the Creative } \\
\text { ibution License. }\end{array}$ \\
\hline 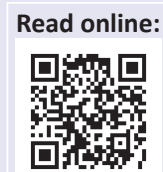 & $\begin{array}{l}\text { Scan this QR } \\
\text { code with your } \\
\text { smart phone or } \\
\text { mobile device } \\
\text { to read online. }\end{array}$ \\
\hline
\end{tabular}

The author asks whether the notion of ubuntu truly exists within contemporary South African society and how the experiencing of South Africans' embodiment can be connected to $u b u n t u$ - especially amongst black people. The notion of $u b u n t u$ is briefly explored within law and theology. The author has recently proposed a model for a contemporary theological anthropology as 'embodied sensing' which functions within the intimate relationship of the lived body, experiencing in a concrete life-world, language, and the 'more than'. It is from this perspective that the notion of $u b u n t u$ is explored.

\section{Introduction}

In September 2014, the South African Human Rights Commission (SAHRC) issued an appeal that the evictions of illegal land dwellers must be done humanely. This report was in reaction to an enquiry into the forced removal on 02 and 03 June 2014 of 800 families in Lwandle, Cape Town, during the middle of winter from land belonging to the South African Roads Agency Limited (SANRAL).

The human rights commissioner concluded that 'we have got to look at evictions in a humane way in the spirit of Ubuntu' (News24 2014).

What is this 'spirit of $u b u n t u$ ' and how do we recognise it? In the eviction of these 800 families in Lwandle during the bitter Cape Town winter, it appears as if there was very little regard for ubuntu and for the bodies of these land dwellers in the actions of the authorities. Does ubuntu exist for these land dwellers and other South Africans, and how do their bodies and their concrete bodily experiences relate to the notion of $u b u n t u$ ?

\section{Does ubuntu exist?}

If the 'spirit of ubuntu' could so easily be abandoned in the case of the Lwandle evictions, this question can rightly be asked regarding the prevalence of $u b u n t u$ in South African society.

Within Africa, the concept of personhood or humanness is expressed in the notion of ubuntu. Khoza (2011:437) writes that this forms the basis of all healthy relations in African societies. He continues that the contemporary employment of $u b u n t u$ in intellectual circles can be traced to Pan-Africanism which is 'the political expression of an intellectual and spiritual movement' that was prevalent in West African and later southern African thinking during colonialism and thereafter. The principal message:

Lies in the indication that we, as Africans, believe that we have special distinctive modes of behaviour, expression and spiritual self-fulfilment: this is something that has been challenged by destructive Western thought and belief but still lies embedded in our collective consciousness. (Khoza 2011:438)

The notion of $u b u n t u$ is expressed in ancient African proverbs, for example, the Nguni saying which translates to 'a person is a person through other persons', the Xitsonga expression 'one finger cannot pick up a grain', and the traditional Xhosa proverb 'no genius is so clever that he can scratch his own back. We are all interdependent'. The quintessence of these axioms is that 'one's humanity (humanness), one's personhood, is dependent upon one's relationship with others' (Khoza 2011:439).

The notion of $u b u n t u$ as a unique philosophical expression of African personhood is predominantly used in South Africa within the spheres of theology and law. Within law ubuntu is explored as a theory with regard to human rights and human dignity.

The notion of ubuntu gained prominence within theology through the influential voice of Archbishop Desmond Tutu, also in his capacity as the Chairman of the Truth and Reconciliation 
Commission (TRC). In Tutu's ubuntu theology the focus is on reconciliation, on the joining of apparent opposites and the restoration of the humanity and dignity of the victims of violence, but also that of the perpetrators of violence. This is expressed in the words of Desmond Tutu (1999:35), who wrote that 'our humanity was intertwined'.

\section{Ubuntu and the law}

The notion of $u b u n t u$ forms the foundation for constitutional order and in a claim made in 2004 by court members, it is stated that the spirit of ubuntu, part of the deep cultural heritage of the majority of the population, suffuses the whole constitutional order' (Gade 2012:487). It is also asserted by the South African Constitutional Court that ubuntu 'is the underlying motif of the Bill of Rights' (Metz 2011:534). Thaddeus Metz then builds upon this assertion to advocate ubuntu and its maxim, 'a person is a person through other persons', as a moral theory for human dignity and an account for human rights within the South African Constitution.

Metz (2011:540) writes that this moral theory is grounded in 'a salient South African valuation of community' and interprets the maxim of ubuntu as 'one becomes a moral person insofar as one honours communal relationships'. He (Metz 2011:540) continues that actions are wrong, not only when they harm other people or degrade their autonomy, but when they are unfriendly, in the sense that they 'fail to respect friendship or the capacity for it'. Metz (2011:545) then argues that human rights violations should be interpreted as 'serious degradations of people's capacity for friendliness', where disrespect is seen as a 'significant degree of anti-social behaviour'.

Such a moral theory where ubuntu (as humanness) is conferred on another person through solidarity with one another and care for each others' quality of life within the contexts of communal relationships, presents a new dimension to the notion of human dignity (Metz 2011:559). The question can then be asked if it is at all possible to confer ubuntu on another person. A further enquiry can be made whether ubuntu is indeed a 'deep cultural heritage' that underlay conceptions of human dignity and humanness in South African communities?

\section{Ubuntu and theology}

The question of the restoration of humanness and justice is one that theology has been struggling with, also during the proceedings of the TRC. Desmond Tutu (1999:34) also connected the idea of friendliness to $u b u n t u$, and describes persons with $u b u n t u$ as people who are 'generous, hospitable, friendly, caring and compassionate'.

The primary association of $u b u n t u$ within theology is that of reconciliation, forgiveness, the restoration of human dignity and justice as well as the interconnectedness amongst people. This relational notion of personhood is advocated by Uzukwu (1996:35) to reconstruct African societies and the church. He writes that this notion should be the guiding principle in Africa for democratic and human rights as well as complete respect for the local and universal church as a testimony of transformation in society.

The understanding that forgiveness is part of $u b u n t u$ is shared by Khoza Mgojo, one of the TRC commissioners and former president of the South African Council of Churches (SACC), who said 'that if you have this, then you must forgive, but not forget' (Gade 2012:491).

The idea of Desmond Tutu that the humanity of both the victims and perpetrators of Apartheid was intertwined reflects the concept of the interconnectedness amongst people. Tutu (1999:35) explains this idea, saying that 'in the process of dehumanizing another, in inflicting untold harm and suffering, the perpetrator was inexorably being dehumanized as well'. Another former TRC commissioner, Bongani Finca, clarifies this concept of interconnectedness as an integral aspect of $u b u n t u$, explaining that a person is a person because of other people, which an individual lives in a community and not in isolation. Finca (Gade 2012) expands further, saying that it is of greater importance within ubuntu to restore communal harmony than to secure punishment, and that:

Ubuntu does not focus on what has been done to you, ubuntu focuses on how we can be restored together as a community, so that we can heal together ... because we can only be fully human when we are human together. (p. 493)

Victims and perpetrators then should assist each other in the process of healing.

The South African theologian Michael Battle (1997:5) writes that this idea of interconnectedness and of restoration is captured in the ubuntu theology of Desmond Tutu, that it has the capacity to restore humanity and dignity and 'of creating a sense of mutuality among people who are alienated from one another'

\section{On the existence of ubuntu}

In his thought-provoking, hard-hitting - and in a sense 'prophetic' - article, the sociocultural anthropologist and intercultural philosopher Wim van Binsbergen (2001:71) argues that in the ubuntu industry, 'ubuntu is a tool for transformation in a context of globalisation'. He describes the promotion of ubuntu as follows:

A regional intellectual elite, largely or totally weaned away from the village and kin contexts to which ubuntu philosophy explicitly refers, employs a globally circulating and in origin primarily North Atlantic format of intellectual production in order to articulate, from a considerable distance, African contents reconstructed by linguistic, ethnographic and other means which are largely unsystematic and intuitive. (Van Binsbergen 2001:72)

His basic argument is that ubuntu is a globalised construct by southern African intellectual elite (politicians, academics, theologians and managers) and that it is deeply disconnected 
from any original or authentic contemporary form of village life and world-view, or on precolonial rural life. He views it more as prophetic, in the sense that it endeavours to rectify social ills in urban, globalised southern Africa, and also as utopian, because:

The images of concrete social life featuring in the statements of ubuntu do not have to correspond to any lived reality elsewhere ... to merely depict, through social imagery... an application of the precepts contained in ubuntu. (Van Binsbergen 2001:73)

However, he is convinced that ubuntu as a globalised construct will succeed because it functions under the guise of an ancestral model which is quite appealing to urban, globalised people and because it is especially appealed to in solving 'seemingly unsolvable conflicts and insurmountable contradictions' (Van Binsbergen 2001:74).

He is scathing in his evaluation of the effectiveness of the TRC, writing that it can be misleading 'to suggest that a RomanAnglican Christian model of confession and absolution epitomises the ancient Southern African world-view as subsumed under the concept of $u b u n t u$ ' (Van Binsbergen 2001:76). His fear is that the appeal to fellow-humanity can serve as a social lubricant in real situations of conflict which could then obscure real divisions based on class, language, gender, ethnicity, bodily appearances, as well as religious and political affiliations. He regards the idea that a perpetrators' humanness could be restored by their victims 'at no greater cost than admission of guilt and offering of apologies' as a fallacy and that the terms of reconciliation was set by 'European and White dominance' (Van Binsbergen 2001:76).

Why I am tempted to call his article of 2001 'prophetic', is the interpretation of the warnings he sounded in the light of the Lwandle evictions in Cape Town 13 years later, and the dramatic increase in social unrest during the last few years in South African townships. Van Binsbergen (2001:77) regards the use of ubuntu in the context of the TRC as questionable and as a 'manipulative repression of resentment and anger'. He acknowledges that there was a huge shift of social, economic and political power after 1990, but that profound 'relations of inequality' were not addressed between men and women, between the middle classes and the poor, between the youth and the older generation, between the noneducated and the educated and between the landless and the land-owners. I would argue that there is also an unequal relation of power between people living in rural communities and city-dwellers, and that Van Binsbergen's evaluation of ubuntu as a global construct focusses heavily on the experiences of people in cities, and does not adequately accommodate how the notion of $u b u n t u$ does permeate village life in rural communities.

Van Binsbergen (2001) asks the provocative question whether there is not:

The danger here of ubuntu being turned into a populistic, mystifying ideology, dissimulating the real class conflict at hand and in doing so, the less powerful Blacks are persuaded to bend the knee to the more powerful elite as soon as the latter wave the flag of ubuntu? (p. 77)
This view is supported by Matolino and Kwindingwi (2013:198) when they argue that ubuntu as an ideology is not 'well rooted in the ethical experiences of modern people qua moral beings' and that $u b u n t u$ as an ethical solution does not hold 'the capacity and context to be an ethical inspiration or code of ethics' in the social context of South Africa. Ubuntu is a variation of the 'narratives of return' which is inspired by a belief in 'the essence of being African' before the time of slavery and colonialism (Matolino \& Kwindingwi 2013:199). The problem with such an 'authentic African mode of being' is that it portrays Africans as incapable of individual and opposing thoughts and it renders life in Africa hegemonic in striving towards this ideal mode of being (Matolino \& Kwindingwi 2013:199).

Being African does not mean the same thing for all people in sub-Saharan Africa and in this way ubuntu, as a narrative of return, is an effort to revive an outdated mode of being (Matolino \& Kwindingwi 2013:201). Matolino and Kwindingwe (2013) are not against the advocacy of Afrocentrism, but argue that $u b u n t u$ :

Is only advanced to serve a certain Africanist agenda when it best suites the elite' and that ordinary citizens employ it, it is 'nothing more than a catch phrase with soap opera soothing qualities. (p. 202)

I shall therefore continue to explore this question as well as others with regard to the existence of $u b u n t u$, the employment of this notion in theology as it pertains to forgiveness, reconciliation, the loss and restoration of humanness from the perspective of theological anthropology as embodied sensing.

\section{Theological anthropology as embodied sensing}

Based on an interdisciplinary enquiry into the corporeal turn in a variety of disciplines and theology, I have recently proposed a model for theological anthropology as 'embodied sensing' - a contemporary theological anthropology with a sentiment of the flesh and a sensitivity to the textures of life. This is a contemporary theological anthropology that takes the body and the experiences of the body seriously as a site of knowledge and as a guiding principle within theological anthropology. Such a theological anthropology functions within the intricate and complex connection of the living body, language and experiencing in a concrete life-world with an openness to the 'more than' (Meiring 2014:283).

The word 'sensing' is an effort to move away from the subject-object distinction to a more participatory approach and, as the linguistic philosopher and psychologist Eugene Gendlin (1997:15) phrases it, 'to speak from how we interact bodily in our situation'. It moves away from a pure cognitive, objective approach to sensing, derived from the Latin word sensus, which expresses the faculty of thought, feeling and meaning (Meiring 2014:284).

The 'living body' stands in a dynamic relationship with its context, with its biology and with its ecology (the environments it interacts with). It is contained by its skin, 
but also extends beyond its skin to the influences it has on its environment. Continued interdisciplinary dialogue is crucial in the ongoing process of further developing and expanding the notion of the living body (Meiring 2014:285). It can be expanded to include, for example, the notion of the vulnerable body when speaking of sin, and how people carry trauma and other memories in their bodies, also from generation to generation (Meiring 2014:288).

It is clear from the exploration of the corporeal-linguistic turn that there exists a very close relationship between language, the body and experiencing. David Kelsey is keenly aware of the importance of language in wisdom literature and the normative connection between the correct use of language and complex practices. He views humans as the social, intentional, bodied enactors of complex practices that include the use of language. Language is then an integral part of wise practices in which it is used in such a way that it remains true to the nature and purpose of the relevant practice, and responds to the realities of the larger public context. Meiring (2014:288) also acknowledges the interchange between a living body and its capacity for language, and the way in which language is intimately connected to a culture's rituals, myths, symbols and images. According to Gendlin (1997:28), the body has an implicit knowing function that includes knowing the language, and how it is relevant to a concrete situation. This kind of bodily knowing (which includes language) is about a living body continuously interacting with its environment.

The process of 'embodied sensing' is not necessarily an easy or transparent process, because as Gendlin (1997:17) puts it, in experience there is 'the implicit language unable to come, struggling, trying to come' in the difficult process of languaging a particular sensed experience. There is a tension in the relationship between language and bodily experience. Gendlin refers to the 'more' of bodily experiences meaning that language and experience cannot be replaced by each other, and that there is a part of experiencing that can never be fully language, even though it is affected by the use of language. The challenge for a contemporary theological anthropology as embodied sensing is to capture this embodied experiencing, the 'felt sense' of bodily experiences, and to listen to the 'unsaid' of the body. Then theological anthropology as embodied sensing truly has a sentiment of the flesh and a sensitivity to the textures of life (Meiring 2014:291).

The 'more than' can refer to a variety of ideas or concepts or theological thought experiments and articulations. David Kelsey (2009:268) refers to the 'epistemic mysteriousness' of living human bodies, that not all manner of knowing of the human body can be exhausted, and that the Trinitarian formula of humans being created by 'the Father through the Son' grounds our knowability 'in the very life of God'. Living human bodies are amazingly complex and in this sense they are 'inexhaustible objects of knowledge' (Kelsey 2009:268); this ties in with what Todres (2011:185) describes as 'the unsaid' of the human body and the idea that not all human bodily experiences can be languaged. Todres (2011:185) also expresses the 'unsaid' in the idea that the experiences of spirituality in everyday life 'are grounded by the palpable lived experience of meeting a mystery that is always in the excess of the known'. His concept of the living body is that it is not merely an object encapsulated by skin, but that it is a subjectivity that is 'intimately intertwined with what is there beyond the skin' (Todres 2011:185).

Flowing from this model for a contemporary theological anthropology as 'embodied sensing', the bodies and the experiences of black people within a concrete life-world (southern Africa) should be taken seriously as a source of revelation and a site of knowledge when exploring the notion of ubuntu.

\section{Black bodies in precolonial and colonial South Africa}

How were the bodies of black people perceived and portrayed in the writings of early travellers and missionaries? What were the experiences of black people during colonialism and Apartheid, and how can it be connected to the notion of ubuntu in South Africa?

Both the antislavery movement and the notion of spreading the Gospel to 'heathen nations' were rooted in the humanitarian movement, which had become stronger since 1760 . Travellers to Africa also published their observations, and the British public were increasingly able to form perceptions of Africans living in southern Africa. These narratives often focussed on the conditions of physical bodies of people on a slave ship with the idea that the pain and suffering would forge a bond between the oppressed and those willing to help (Magubane 1997:2-4).

The trope of the 'Noble Savage' figured strongly in the travel writings of William Burchell who in 1815 described young men as firm, walking with freedom and boldness whereas women were portrayed with pity and disgust. The Khoikhoi and San, although considered 'Noble Savages', were portrayed as weak and feminine compared to the truly 'manly tribes' of the Nguni, such as the Xhosa (Magubane 1997:7-9). William Burchell (1815), for instance, was torn between this ideal and his belief, stating that 'although "savage society" had its advantages, it cannot pose an effective challenge to European civilisation' (Magubane 1997:18). Africans were purely measured by European standards with the hope that one day they might reach the European standard of civilisation.

The public exhibition on Piccadilly, London, of 'The Hottentot Venus' was probably the most prominent body on display of a black woman (as colonial subject) in the 19th century and remained so until 1976 when her skeleton and bodycast were removed from public display at the Museum of Natural History in Paris (Holmes 2007:65). Saartjie Baartman became 'the most famous theatrical attraction in Piccaddilly' during the juncture of two critical moments in racial attitudes 
in England (Holmes 2007:65). It was the end of 'sentimental primitivism' and the beginning of an era of 'the new pseudoscience of ethnology' that went hand in hand with white imperialism, the economic exploitation of colonies, and scientific racism (Holmes 2007:70).

Lahoucine Ouzgane, a scholar in postcolonial theories, refers to the work of Arthur Saint-Aubin who investigated the way in which a certain trope of the black body was constructed as normal through Western science and medicine in the 18th and 19th centuries. This black body had a huge penis and an insatiable appetite for sex. This way of pathologising the black male through the process of 'othering' was done to elevate the European as superior and different to other races.

Ouzgane (2002:244) concludes that 'at the core of this body politics lurked an intense white masculine insecurity and anxiety'. White bodies were considered to be civilised and controlled, whereas black bodies were portrayed as 'oversexed and savage' (Ouzgane 2002:244). To maintain the 'truth' of the structures and institutions of these colonial empires, black bodies were disciplined (including torture and death) and made docile.

After the 19th century, 'this surveillance was an internal and external mechanism of docility' that was used by white people to determine what was possible for black bodies, and when necessary also for white bodies. African bodies and sexuality became the touchstone for the justification of colonial enterprise objectives - 'to civilise the barbarian and savage natives of the dark continent' (Tamale 2011:14). It was a mission that was implemented through paternalism, brutality, force, arrogance, humiliation and insensitivity.

\section{The black body during Apartheid ... and those of poor white people}

The portrayal of black bodies by artists during Apartheid gives some indication of how embodiment was experienced by the majority of the South African population.

Peffer (2009:41) writes that 'South African artists have long used the image of the human body in distress as a sign of the inhumane conditions in their society'. Peffer (2009:41) continues that abused bodies became a common sight in the 1970s and that in the art of this decade the human body was often portrayed through 'animal transformations' as a way to designate how 'this everyday brutality of Apartheid was internalized and how it might be exorcised'. Artists confronted the viewer with potent questions about the relationship between 'corporeal experience to ideas about animality, community, and the sacred' (Peffer 2009:41).

Before the official onset of Apartheid in 1948 with the election of the National Party into government, there was a response to modernity as impressed by European colonialism. Peffer (2009:6) writes that black artists tend to 'illustrate the lives of cosmopolitan educated Africans', referring to John Koenakeefe Mohl who taught easel painting from his home in Sophiatown in the 1940s and who declared that his art would ensure that 'the world ... realize that black people are human beings'. The ensuing 'township art' mirrored the assumptions that white South Africans wanted to foster around black South Africans.

One of the most disturbing pieces of art is the installation of Jane Alexander entitled The Butcher Boys, which was exhibited for the first time in 1986 at the Market Theatre, Johannesburg. Peffer (2009:65) describes the group as 'horrifically menacing, but their wounded look is also seductive'. He (Peffer 2009:65) writes that they are the three graces of Apartheid, their 'zoomorphic transformation' meant 'to evoke the psychological inscription of daily cruelties and hypocrisies inflicted, and self-inflicted' on the citizens of South Africa. He continues that Alexander appeals to 'sanity in a society gone sick under forty years of a hyper-rational authoritarian regime' (Peffer 2009:65). The installation is a demonstration of the 'sinister, inhuman, and amoral nature' (Peffer 2009:65) of the whole Apartheid society. The entire society is depicted as a monstrosity.

The depictions of back bodies were in sharp contrast to the way in which white bodies were perceived and how especially white masculinities were constructed. Some Afrikaner men formed a 'Republican masculinity' (ed. Morrell 2001:15). Morrell (ed. 2001:15) describes this 'Republican masculinity' as a modernised form of ethnic masculinity, built on the notion of racial superiority over blacks, and a desire for freedom from the British. This masculinity put the focus on 'the importance of independence, resourcefulness, physical and emotional toughness, (the) ability to give and ... take orders, of being moral and God-fearing' (ed. Morrell 2001:15).

The exception to the dominant Republican masculinity and the experiencing of their embodiment was that of the poor white people whose bodies were categorised with those of the black population. Willoughby-Herard (2007:480) writes that the Carnegie Corporation Poor White Study that took place between 1927 and 1932 served as 'a lynchpin to the political consolidation of Afrikaner Nationalism' in the era of grand Apartheid from 1948 until 1994. Willoughby-Herard (2007:480) argues that the 'regulation, constraint, and racial markings of poor whites as irretrievable and degenerate, as "like blacks"' played an important role in the creation of Apartheid, in the same way that other practices dehumanised black people, coloured people and Asian people. He continues that the fear of 'white degeneration', the policing of white identity and the significance of the 'white primitive' contributed to the establishment of white nationalism and white supremacy (Willoughby-Herard 2007:482). Scientific racism had to protect the white body from the potential of 'genetic and racial barbarism, primitivism and degeneration' (Willoughby-Herard 2007:487).

The 'poor white problem' could probably also explain the eagerness with which the Dutch Reformed Church in 1935 expressed their opposition to the idea of racial intermarriage 
whilst advocating cultural and spiritual segregation in their 'Missionary Policy' (Loubser 1996:324). Furthermore, this is possibly why the Prohibition of Mixed Marriages Act (No. 55 of 1949) was the first major piece of Apartheid legislation to be passed after the National Party took power in South Africa in 1948, prohibiting the marriage between people of different races, and therefore prohibiting the contamination of white bodies by black bodies.

\section{The Truth and Reconciliation Commission and experiences of embodiment}

A well-known attempt to clear society of the monstrosities of Apartheid was made in the form of the TRC. The horror people felt at stories of perpetrators drinking and having a barbecue whilst burning the body of a struggle activist, and the opinion that such perpetration could only come from monsters was met by the following response from Archbishop Desmond Tutu (2013); he writes that:

\begin{abstract}
Yes indeed, these people were guilty of monstrous, even diabolical, deeds on their own submission, but - and this was an important but - that did not turn them into monsters or demons. To have done so would mean that they could not be held morally responsible for their deeds. Monsters have no moral responsibility. (p. 43)
\end{abstract}

Bethlehem (2006:78) explores how the TRC produced 'consensual narratives of the Apartheid past' and how the body repeatedly featured in these narratives. She refers to the notion of 'body-politics-as-system' that is passed back to the trope of 'system-as-body', which in turn devolves back to 'the body as the body of the victim'. She continues that the TRC laid claim to the idea of 'the nation as a physical body, a generically South African ... individual'. The corpse or remains of the victims of Apartheid became the 'privileged site of intersection' when witnesses appealed to corporeal violations given the way in which victims' bodies were violated (Bethlehem 2006:78). She writes that the 'descriptions, representations and conflicts around bodies in various states of mutilation, dismemberment, and internment within the terror of the past' were the 'visual core' of the TRC (Bethlehem 2006:82). Family members repeatedly pleaded for the remains or body parts of their loved ones, 'making their visibility, recovery and repossession a metaphor for the settlement of the past of Apartheid' (Bethlehem 2006:82).

The sociologist Didier Fassin (2007:xv) is concerned with the 'inscribing of historical time onto flesh, the social determinations of individuals' biological fate' and meaningmaking of the present through remembering. He continues to cite Mbembe who writes that the West still finds it difficult to recognise "the body and flesh of "the stranger" as flesh and body just like mine' (Fassin 2007:xv) as well as the idea of a common humanity shared with others.

History is for him not simply a sum of different narratives, but 'it is also what is inscribed within our bodies and makes us think and act as we do' (Fassin 2007:xix). He writes that the body is not just a manifestation of a person's presence in the world, but it is also a site where the past has left its mark or as he puts it:

The body is a presence unto oneself and unto the world, embedded in a history that is both individual and collective: the trajectory of a life and the experience of a group. (Fassin 2007:175)

The 'moral signature' of the TRC was the employment of two visual 'tools', namely the practice of exhumation and 'of one body held by another' (Bethlehem 2006:83). Bethlehem (2006:83) continues that 'the scar put on display before the commission, locates the self as the site of violation'. The exposure of the scar in public also became an act of purification and a purging of the social body (Bethlehem 2006:84). The focus on the body during the TRC hearings delivered a 'mnemonic production' where the surface of the body became a site of memory. The sight of the violated body allowed the body to be 'stabilised as the site of memory' (Bethlehem 2006:85).

The pain of the body is shared. This idea ties in with the theological reflection of Ganzevoort (2008:24) who puts forward a reinterpretation of scars as stigmata. He writes that 'the scars on our body and soul tell the story of wounds inflicted upon us', and that traumatic experiences are accepted and integrated as identity markers (Ganzevoort 2008:23). Stigmata then transcend the scars of individual traumatic experiences and become 'prophetic markers of resistance against the normative cultural stories of wholeness and perfection' (Ganzevoort 2008:28).

\section{Language and ubuntu}

According to Kelsey (2009:303), it is very important that language is not used in a way that is false or deceitful, as distorting the practice through the deceitful use of language is to deform the quotidian created by God. Linguistic philosophy has focussed the attention on the challenge in languaging human experiences, and the effort it takes to stay true to the truth of experiences through the use of language. The living body is part of language as a discourse, which Gendlin (1997:28) expresses in his assertion that 'speaking is a special case of bodily interaction'. What kind of 'bodily knowing' was invoked throughout the centuries as black and white bodies interacted with its environment in South Africa? How did language influence this 'bodily knowing'? The previous sections are an overview of the bodily interactions in the precolonial, colonial and Apartheid history of South Africa as well as within the confines of the TRC.

Gade (2012:486) makes the claim that since the Nguni term ubuntu is found in different variations in other language groups around sub-Saharan Africa (e.g. 'umundu' in Kenia, 'bumuntu' in Tanzania, 'vununtu' in Mozambique and 'bomoto' in the Democratic Republic of Congo), 'the basic idea of ubuntu is shared by many indigenous peoples in sub-Saharan Africa under different names'. Van Binsbergen (2001:54) writes that the root '-ntu' is used for a human 'from the Cape to the Sudanic belt'. Ubuntu became associated 
with the Nguni proverb 'umuntu ngumuntu ngabatu', which is translated as 'a person is a person through other persons' (Gade 2012:487).

However, the irony and dilemma is that the word 'abantu' (i.e. to be a person) as a qualification of the notion of $u b u n t u$ has been used during the racial oppression of Apartheid to only denote black people as 'Bantu' (Gade 2012:496). The tragedy is that by only using the word 'bantu' for black people, white people in South Africa have removed themselves from the African notion of $u b u n t u$, have put themselves outside the circle of those who are considered to be persons. The question could then be posed whether white people have the right to invoke the notion of ubuntu. Van Binsbergen (2001:55) writes that in colonial and postcolonial Africa the root '-ntu' only refers to a 'local, autochtonous humanity' which stands opposite those who are historically and bodily not local and whose humanity may then be questioned or denied. He makes the statement that:

The colonial officer, the missionary, the anthropologist, the capitalist farmer, the industrial manager and entrepreneur, for a century or more right up to the establishment of Black majority rule in Southern Africa, could never (and would never) aspire to the status of muntu in the eyes of the African majority population. (Binsbergen 2001:55)

\section{The 'more than' of ubuntu}

The 'more than' in the proposed model for theological anthropology as 'embodied sensing' can refer to a variety of ideas or concepts or theological thought experiments. There is a 'more than' to the eventing of human bodily experiences in a concrete life-world; there is a 'more than' to the richness of textured bodily life that cannot easily be conveyed into theological articulations. Kelsey (2009:556) expresses this 'more than' in the notion of eccentric existence, and the continuity between physical human bodies and glorified bodies as 'God-related bodies', living in 'the sociality of community-in-communion' where they are recognisable as an individual with unconditional dignity and unqualified respect (Meiring 2014:292).

Nolte-Schamm (2006:377) writes that many theologians link ubuntu to the theological doctrine of imago Dei. Battle (1997:64) writes that Desmond Tutu has turned the notion of ubuntu 'into a theological concept in which human beings are called to be persons because we are made in the image of God'. Gade (2012:494) also explores the question of who counts as persons according to South Africans of African Descent (SAADs). He divides the answer into two categories, namely 'all Homo sapiens' and 'only some Homo sapiens'. The subanswers are divided into 'only Homo sapiens who meet the criterion of being black', 'only Homo sapiens who meet the criterion of having been incorporated into personhood' and 'only Homo sapiens who behave in a morally acceptable manner'. He concludes that it would be ethically illegitimate to argue for any exclusive ideas of the nature of $u b u n t u$ in post-Apartheid South Africa (Gade 2012:500).

\section{Conclusion}

I would concur with Von Binsbergen that ubuntu is more of a globalised construct than it is connected to any authentic contemporary form of village life and world-view, or original rural life in precolonial time. I also support his anxiety that an indiscriminate and insensitive appeal to ubuntu as fellowhumanity can suppress real situations of conflict and divisions in contemporary South African society as illustrated by the Lwandle evictions. It can become a kind of disembodied ubuntu. At the same time I would agree that ubuntu as a globalised construct will succeed because it appeals to urban, globalised people under the guise of an ancestral model and has the appearance of solving unsolvable contradictions.

However, it cannot be promoted without a profound consideration for the bodily experiencing of black people in their concrete life-worlds throughout the heart-wrenching history in South Africa from the time of the first explorers and missionaries in the 15th century, the colonial and Apartheid periods and in post-Apartheid South Africa. There is an implicit kind of bodily knowing in the continuous interacting of living bodies with its environment throughout this 500-year history, a bodily knowing where the black body has often been denied its dignity and humanity, where it has been perceived as subhuman and uncivilised.

The word 'bantu' has ironically supported the trope of the wild, dark, unpredictable and uncivilised barbarian albeit a 'noble savage', a trope that has also has been reinforced by the employment of the doctrine of the imago Dei, only referring to some part of the creation and its creatures, often excluding black people and their bodies. As a globalised construct I would argue that everyone in South Africa has the right to invoke the notion of $u b u n t u$, but that it would take a considerable time for a new bodily knowing to develop as an alternative to the 500 year old narrative. Ubuntu has barely penetrated the skin of white bodies. I would also appeal to a deep sensitivity to the experiences of black people and the experiencing of their embodiment when evoking 'the spirit of $u b u n t u^{\prime}$ in law and human rights and when endeavouring to construct any theology of $u b u n t u$ based on human dignity, fellow-humanity, human interconnectedness and restorative justice.

\section{Acknowledgements Competing interests}

The author declares that he has no financial or personal relationships which may have inappropriately influenced him in writing this article.

\section{References}

Battle, M., 1997, The ubuntu theology of Desmond Tutu, The Pilgrims Press, Cleveland, $\mathrm{OH}$.

Bethlehem, L., 2006, Skin tight: Apartheid, literary culture and its aftermath, UNISA Press, Pretoria, Koninklijke Brill NV, Leiden.

Fassin, D., 2007, When bodies remember: Experiences and politics of AIDS in South Africa, University of California Press, Berkeley, CA and Los Angeles, CA. http:// dx.doi.org/10.1525/california/9780520244672.001.0001 
Gade, C.B.N., 2012, 'What is ubuntu? Different interpretations among South Africans of African descent', South African Journal of Philosophy 31(3), 484-503. http:// of African descent', South African Journal of Phil
dx.doi.org/10.1080/02580136.2012.10751789

Ganzevoort, R.R., 2008, 'Scars and stigmata: Trauma, identity and theology', Practical Theology 1(1), 19-31. http://dx.doi.org/10.1558/prth.v1i1.19

Gendlin, E., 1997, 'How philosophy cannot appeal to experience and how it can', in D.M. Levin (ed.), Language beyond postmodernism: Saying and thinking in Gendlin's philosophy, pp. 3-41, Northwestern University Press, Evanston, IL.

Holmes, R., 2007, The Hottentot Venus. The life and death of Saartjie Baartman: Born 1789 - buried 2002, Jonathan Ball Publishers, Johannesburg and Cape Town.

Kelsey, D.H., 2009, Eccentric existence: A theological anthropology. Volume 1 \& 2, Westminster John Knox Press, Louisville, KY.

Khoza, R.J., 2011, Attuned leadership: African humanism as compass, Penguin Books, Johannesburg.

Loubser, J.A., 1996, 'Apartheid theology: A “contextual theology” gone wrong?', Journal of Church and State 38(2), 321-337. http://dx.doi.org/10.1093/ jcs/38.2.321

Magubane, Z., 1997, 'The body of the savage: Humanitarian narratives 1800-1827', Social Dynamics 23(1), 1-21. http://dx.doi.org/10.1080/02533959708458617

Matolino, B. \& Kwindingwi, W., 2013, 'The end of ubuntu', South African Journal of Philosophy 32(2), 197-205. http://dx.doi.org/10.1080/02580136.2013.817637

Meiring, J.J.S., 2014, 'Theology in the flesh: Exploring the corporeal turn from a southern African perspective', PhD thesis, Department of Theology, Vrije Universiteit.

Metz, T., 2011, 'Ubuntu as a moral theory and human rights in South Africa', African Human Rights Law Journal 11, 532-559.
Morrell, R. (ed.), 2001, Changing men in Southern Africa, University of Natal Press, Pietermaritzburg.

News24, 2014, 'SAHRC: Evictions must involve ubuntu', viewed 10 September 2014, from http://news24.com/SouthAfrica/SAHRC-Evictions-must-involveubuntu-20140910

Nolte-Schamm, C., 2006, 'African anthropology as a resource for reconciliation: Ubuntu/Botho as a reconciliatory paradigm in South Africa', Scriptura 93, 370-383.

Ouzgane, L., 2002, 'Guest editorial: An introduction', The Journal of Men's Studies 10(3), 243-245. http://dx.doi.org/10.3149/jms.1003.243

Peffer, J., 2009, Art and the end of Apartheid, University of Minnesota Press, Minneapolis, MN.

Tamale, S., 2011, 'Introduction', in S. Tamale (ed.), African sexualities: A reader, pp. 1-7, Pambazuka Press, Oxford.

Todres, L., 2011, Embodied enquiry: Phenomenological touchstones for research, psychotherapy and spirituality, Palgrave Macmillan, Hampshire.

Tutu, D.M., 1999, No future without forgiveness, Rider Books, London.

Tutu, D., 2013, 'What about justice? Arguments for restorative justice', in J. Allen (ed.), God is not a Christian: Speaking truth in times of crisis, pp. 37-47, Rider, London.

Uzukwu, E.E., 1996, A listening church: Autonomy and communion in African churches, Orbis Books, Maryknoll.

Van Binsbergen, W., 2001, 'Ubuntu and the globalisation of southern African thought and society', Quest 15(1-2), 53-89.

Willoughby-Herard, T., 2007, 'South Africa's poor whites and whiteness studies: Afrikaner ethnicity, scientific racism and white misery', New Political Science 29(4), 479-500. http://dx.doi.org/10.1080/07393140701688339 